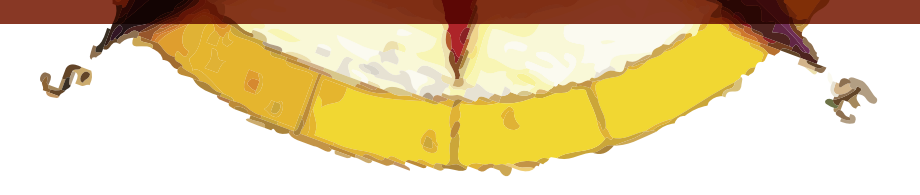

\title{
TOWARDS A FRAMEWORK FOR RESEARCH IN GEOGRAPHICAL EDUCATION
}

\author{
Michael Williams ${ }^{1}$
}

\begin{abstract}
Research is the jewel in the crown of geographical education. Well-conducted and reliable research provides information, insights and understandings accessible to professionals as they go about their daily tasks. It draws on educational research for its methodology and contributes to both the content and methodology of educational research. Research is a deliberate, systematic activity founded on ethical behaviour. However, research in geographical education requires a culture conducive to research and trained researchers supported through funding adequate for them to undertake projects that vary in scale and complexity. This article is based on a framework of research in geographical education that is sufficiently general to locate recent and current studies and enables lines to be drawn between specific studies located in particular places and the components of the framework. The framework is illustrated in Figure $\mathrm{N}^{\mathrm{o}} 1$.
\end{abstract}

Keywords: Educational research, geographical education, framenwork for research

\section{RESUMEN}

La investigación es la piedra preciosa en la corona de la educación geográfica. Una investigación bien desarrollada y fidedigna provee información, hallazgos y entendimiento accesible para los profesionales mientras realizan sus tareas cotidianas. La educación geográfica recurre a la investigación sobre educación en términos de metodología y contribuye a la investigación sobre educación tanto en términos de contenido como de metodología. Investigar es una actividad intencionada y sistemática basada en comportamiento ético. No obstante la investigación en educación geográfica requiere de una cultura conducente a la investigación y a investigadores formados, sostenidos en un financiamiento adecuado para el desarrollo de proyectos, variados en escala y complejidad. Este artículo se basa en un marco de investigación en educación geográfica suficientemente general para posicionar los estudios recientes y actuales y permitir dibujar conexiones entre estudios específicos localizados en lugares particulares y los componentes de un marco que se encuentra representado en la figura $\mathrm{N}^{0} 1$.

Palabras Clave: Investigación educacional, educación geográfica, marco de investigación

1 Emeritus Professor of Education Swansea University, Wales United Kingdom. 


\section{RESUMO}

A pesquisa é a pedra preciosa na coroa da educação geográfica. Uma pesquisa bem desenvolvida e fidedigna provê informação, achados e entendimento acessível para os profissionais enquanto realizam suas tarefas quotidianas. A educação geográfica percorre a pesquisa sobre educação em termos de metodologia e contribui à investigação sobre educação tanto em termos de conteúdo como de metodologia. Pesquisar é uma atividade intencionada e sistêmica baseada num comportamento ético. No entanto a pesquisa em educação geográfica requer de uma cultura conducente à investigação e a pesquisadores formados, sustentados num financiamento adequado para o desenvolvimento de projetos, variados em escala e complexidade. Este artigo baseia-se num marco de investigação em educação geográfica suficientemente geral para posicionar os estudos recentes e atuais e, permitir desenhar conexões entre estudos específicos localizados em lugares particulares e os componentes de um marco que se encontra representado na figura $\mathrm{N}^{\circ} 1$.

Palavras-chave: Pesquisa educativa, educação geográfica, marco de investigação

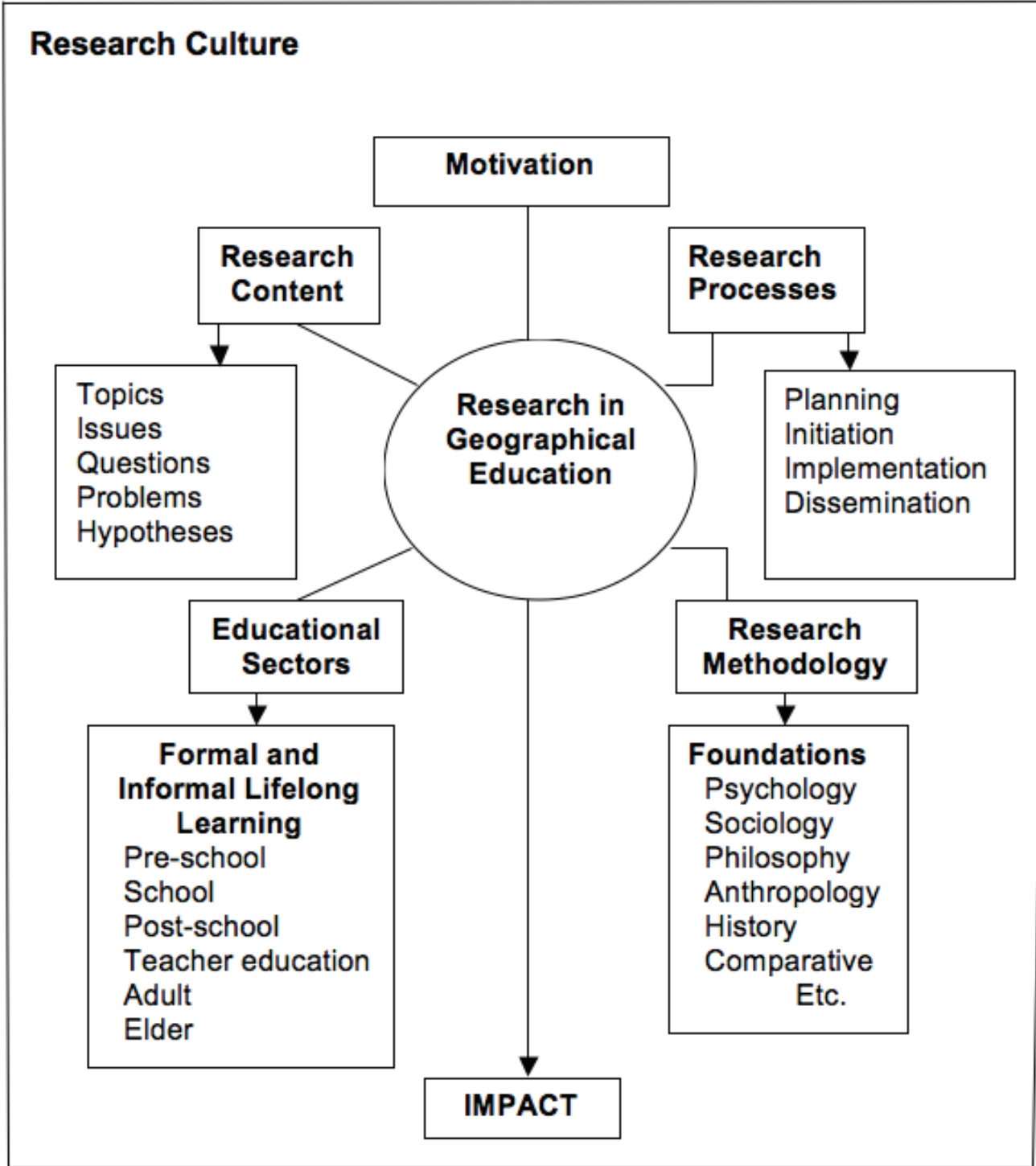

Figure $\mathrm{N}^{\mathrm{o}}$ 1: A Framework for research in geographical education 


\section{A RESEARCH CULTURE}

When Understanding Research in Geographical and Environmental Education: The Role of Research was published in 1996 it had been my intention, as editor, to follow it up with a book of exemplars drawn from current research projects that would illustrate the utilisation of those research methods discussed in that book. However, at that time, finding enough papers of sufficient quality proved very difficult and the attempt was abandoned. This absence of quality research at that time was echoed in an article by Downs (1994) who argued that the field of geographical education lacked the empirical data necessary to guide curriculum decisions and curriculum materials development. Further, he suggested that four needs should be met: a new attitude towards research; a series of baseline studies, a research agenda; and a research clearing house. Since, then a number of important changes have occurred in the overall culture of research in general and these changes have transformed the geographical education research scene. Most notable is the pressure that has been placed on university-based researchers from politically driven initiatives intended to monitor the work of individuals and departments in the interests of demonstrating value for money and improving research standards. The consequence has been a burgeoning of research-focused seminars and conferences, specialist journals and networks.

The drive to demonstrate research output has been accompanied by the need for researchers to publish in prestigious international journals and for all research findings to be rigorously peerreviewed. In this climate, researchers must compete for space in international journals. Clearly, the more international journals in geographical education that exist the more are the opportunities for researchers in the field to submit their papers. The journals themselves have to compete against each other to attract the best papers. For the researcher, there is a need to choose between publishing in either the generic education research journals or those that are specific to research in geographical education. The same choice has to be made when using limited funds to attend conferences: the choice is not only between generic and specialist conferences but also between national and international conferences. Much depends on the researchers' perceptions of prestige.

It is clear from the publications of researchers in geographical education that the bulk of research has been undertaken in universities. This is not to suggest that across the globe all universities employ researchers in geographical education. Indeed, not all universities require all of their academic staff to engage in research. Essential to university culture are the contractual obligations of academics and the incentives provided for them to undertake research. Too often, it would appear, research in geographical education is conducted by geography teacher educators burdened by heavy loads of teaching, practicum supervision and administration. In these circumstances research has to be squeezed into small pockets of time, with only sabbatical leave and uninterrupted vacations offering relief from the day-to-day pressures. Further, the number of geographical education specialists employed in any university is generally small and it is not uncommon to find only one such specialist in some universities. The image of the isolated academic pursuing his or her idiosyncratic research interest is a familiar one. Alongside university academics there are sometimes postgraduate students working towards research degrees and these are the sources of much intensive, original work.

Even when universities promote research in geographical education, the freedom of universitybased researchers to select the topic to study, the methods to be used in undertaking studies and the places where findings will be published will vary between nations according to their political contexts. This freedom will also be limited by researchers' definitions of audience. For university resear- 
chers in geographical education the audience may be limited to other researchers in geographical education though some studies will be motivated to yield findings that are likely to be of interest to other professionals or to policy makers. Of course, there is an encouragement in some societies for school teachers to undertake small-scale research studies, sometimes as action research projects, and here the audience may be limited to the teacher himself or herself or a group of teachers who are concerned with resolving a problem or issue relevant only to their particular school.

Rarely does one encounter research in geographical education undertaken in institutions that only undertake research. Because the bulk of research in geographical education is conducted by teacher educators (Papadimitrou and Kidman, 2012) the focus of most studies is formal school education and this is supplemented by the studies undertaken in the context of higher education. Informal and non-formal geographical education has received much less attention. Lifelong geographical education, defined in terms of education 'from the cradle to the grave', receives scant attention. It would appear to be so obvious that geographical education occurs only in schools, colleges and institutions of higher education and that geographical education for adults and elders is simply ignored (Williams, 2005). I shall return to this latter point later in this article.

Research culture in geographical education is partly defined by boundaries. Language is one important boundary since researchers from minority languages inevitably must translate or arranged to have translated their work into one of the major international languages. The researcher who is able to communicate in two or more of the major international languages is able to access research publications published in those languages and play an active role in a number of single languagebased networks. Obviously, researchers whose first language is, say, French or Spanish but who can communicate easily in English or German or Chinese have access to a wide range of publications, networks and conferences. It is remarkable how few academics from the English speaking world have this facility. To support this generalisation, I would quote from my recent experience of coediting a series of books that have been published in English though the authors have been drawn from various language communities. North America (Canada and the United States of America) (McKeown and Nolet, 2013) and Australasia (Robertson, 2012) are the subjects of two of these books. In the former book there are chapters by 32 contributing authors and in the latter 20 contributing authors. A reading of the hundreds of references quoted in these books clearly indicates the dependence of the authors on an English language literature. By sharp contrast, in the book in the series focused on South America (Soares and Petarnella, 2011) the 21 chapter authors rarely refer to English language publications. However, this is not the case for the book in the series concerned with Chinese Communities (Lee and Williams, 2009) where the role of Hong Kong scholars in bringing Western literature to the attention of mainland Chinese scholars is evident. However, it is worth noting in the references the number of mainland Chinese papers that have been translated into English. The absence of trans-language cross-referencing is a general feature of publications in the field of research in geographical education.

National boundaries constitute another defining feature of the research culture of geographical education. This is not to suggest that there is no evidence of international collaboration. As the books referred to in the previous paragraph demonstrate, these and other anthologies serve to bring together studies undertaken in various countries. An important part of the rationale of these books is that scholars in one country will benefit from the work of scholars in other countries. Given the number of such books (e.g. Haubrich, 1987; Convey and Nolzen, 1997; Gerber and Williams, 2002; Gerber 2003; Lidstone and Williams, 2006), it would be reasonable to expect that cross-referencing 
within nation-based studies would reflect this internationalism. An example of a recent researchbased nation-focused book has been edited by Butt (2011). It is a publication of the Geography Education Research Collective (GEReCO). There is nothing in the title to suggest that this is a narrowly nation-focused book. From the opening paragraphs it is clear that what will follow will be concerned only with England (Northern Ireland, Scotland and Wales are not even included in the index) and not with the United Kingdom. To that extent, this is a 'local' book that limits its horizons to school geography within the borders of England, drawing its evidence from national specialists who address essentially national issues.

The strength of national boundaries is evident in England where scholars generally appear to be unfamiliar with studies undertaken in neighbouring nations. Examples of research work in the field of geographical education that go unnoticed include, in France, the publications of Enjeux contemporains de l'enseignement de l'histoire-géographie sponsored by the Institut Français de l'Éducation and, in Germany, the publications of the Hochschulverband fur Geographie und ihre Didaktik such as the journal Geographie und ihre Didaktik, and those of the Georg Eckert Institut fur Internationale Schulbuch Forschung, including the Journal of Educational Media, Memory and Society (that replaced Internationale Schulbuch Forschung in 2009).

Nation-based studies are valuable for the international community of researchers in geographical education if they address universal questions, problems or issues. This is especially so if the studies contribute to "theory construction or the refinement of research methodologies" (Gerber and Williams, 2000 , p. 212). They are also interesting for the international community if they are focused on research-based experience of pedagogical practice. Especially interesting are research findings that offer carefully collected and rigorously analysed data on good practice. Not all such data are easily transferable across national boundaries and between language communities since the complexities of the social, political and economic contexts in which the data were collected render them difficult to understand. What this points to is the culture of research where any studies are undertaken and in Figure 2 an attempt has been made to clarify the stages of growth in this culture.

\begin{tabular}{|l|l|l|}
\hline \multicolumn{1}{|c|}{ Incipient stage } & \multicolumn{1}{|c|}{ Intermediate stage } & \multicolumn{1}{c|}{ Mature stage } \\
\hline $\begin{array}{l}\text { Individuals researching in } \\
\text { isolation }\end{array}$ & Intra-institutional groups & International groups \\
$\begin{array}{l}\text { Idiosyncratic and changing } \\
\text { substantive focuses }\end{array}$ & $\begin{array}{l}\text { Stable substantive focuses } \\
\text { though subject to personnel } \\
\text { changes }\end{array}$ & $\begin{array}{l}\text { Enduring substantive focuses } \\
\text { that are unaffected by } \\
\text { personnel changes }\end{array}$ \\
Unfunded & $\begin{array}{l}\text { Funded by local and national } \\
\text { organisations }\end{array}$ & $\begin{array}{l}\text { Funded by international } \\
\text { organisations }\end{array}$ \\
$\begin{array}{l}\text { Unsupported by a } \\
\text { professional body }\end{array}$ & $\begin{array}{l}\text { Supported on the margins of a } \\
\text { national professional body }\end{array}$ & $\begin{array}{l}\text { Central to the work of an } \\
\text { international body }\end{array}$ \\
$\begin{array}{l}\text { Dominated by immediate } \\
\text { practical issues }\end{array}$ & $\begin{array}{l}\text { Linking practical and } \\
\text { theoretical issues }\end{array}$ & $\begin{array}{l}\text { Dominated by universal } \\
\text { theoretical issues }\end{array}$ \\
\hline
\end{tabular}


Focused largely on a single sector of a national education system

Undeveloped specialist geographical education research language

\begin{abstract}
Absence of textbooks on geographical education research
\end{abstract}

Lacking any sub-discipline strengths within geographical education

No infrastructure of research focused symposia, conferences, web pages, journals, and other publications

Lacking supportive local and national networks (faceto face and virtual) of researchers in geographical education

Few opportunities for training in research in geographical education
Focused on more than one sector of a national education system

Emergence of a specialist geographical education research language

Introductory textbooks on geographical education research

Emergent sub-discipline strengths within geographical education

Developing nationally based infrastructure of research focused symposia, conferences, web pages, journals and other publications

Developing research-based local and national networks

Limited national opportunities for training in research in geographical education
Focused on lifelong learning in an international context

Use of a sophisticated geographical education research language

An array of established textbooks on geographical education research

Established sub-discipline communities within research in geographical education

Well-developed international infrastructure comprising symposia, conferences, web pages, journals and other publications

Established and effective international networks of researchers in geographical education.

Many international opportunities for training in research in geographical education

Figure $\mathrm{N}^{\circ} 2$ : Stages of Growth in the Culture of Research in Geographical Education (modified from Williams, 1997)

\section{CONTENT}

Useful sources for categorizing the content of research in geographical education are to be found in the bibliographies edited by Foskett and Marsden (1997 and 2002) and an article written by Bednarz (2000). Foskett and Marsden, following on the bibliography edited by Lukehurst and Graves (1972) that focused on the century 1870-1970, while not focused exclusively on research-based publications, listed the details of publications under the following headings: 
A. Geography and Education

Methodological texts in geographical education

Research in geographical education

The geography of education

The changing nature of geographical education: historical and future

Justification of geography in the curriculum

Geography in the National Curriculum in England and Wales

B. Geography in the Curriculum

Learning and teaching geography

- Graphicacy

- Children's learning

- Language

- Teaching styles

- Differentiation and progression

- Special needs

- Developing values and attitudes

Curriculum planning in primary geography

Curriculum planning in secondary geography

Curriculum planning in higher education

Field-work and outdoor education

Curriculum projects in geography

Fieldwork and outdoor education

Teaching resources at primary level

Teaching resources at secondary and tertiary levels 
Assessment and evaluation in geography

Geography as a linking subject

Managing geography

C. Geographical Education in Social Context

Geography and political education

Geography and equal opportunities

Geography and economic and industrial awareness

Geography and the European dimension

Geography and international understanding

Geography and careers

Lifelong geographical and environmental education

D. Environmental Education

E. Geographical and Environmental Education in Other Countries

It should be noticed that these are the principal headings and sub-headings were used within the categories. This is clearly a comprehensive list, demonstrating what was deemed to be important for geographical educators, both researchers and professionals, at the end of the last century.

The categories were used in a review of 107 major articles published from 1992 to 2000 in International Research in Geographical and Environmental Education (Lidstone and Williams, 2006). The authors reported that, "The emphases on graphicacy, children's learning and language may be welcomed as showing that the traditional concerns of geographers are not being ignored but they could also reflect a research agenda that has barely moved on in a quarter of a century. Of great concern is the lack of research on modern technologies such as Global Information Systems" (p.5).

Articles published more recently, from 1992 to 2009, in International Research in Geographical and Environmental Education have been subjected to rigorous analysis by Kidman and Papdimitrou (2012) who report their findings in two papers. From the 526 articles, in terms of their content, they were able to detect three important trends. First, increasing attention has been paid by researchers to sy1labi, curricula, values and attitudes. Secondly, GIS (Global Information Systems) and sustainability are emergent themes for research. Thirdly, teacher education has been the "most recurrent theme".

These findings can be set alongside Bednarz's (2000) attempt to define research in geographical 
education - geography education as she termed it - in the United States. For her, geography education was a sub-field of geography, a hybrid that synthesized geography and education. For the latter, she selected three domains identified by the American Educational Research Association: learning and building theoretical understanding of the learning/teaching/education process; research on teacher education; and improvements of professional practice (classrooms, administration and policy making). This was the basis of a typology she used to review 347 research-based articles. Her categories were:

- Geography teaching strategies and methods.

- Geography learning and thinking research.

- Institutional geography education research.

By far the majority of articles fell into the first category and the fewest were in the learning and thinking category, confirming a previous assessment that geography education research was focused 'on classroom practice and not on baseline theoretical and cognitive issues' (p.138). Compared to the categories defined in a British context by Foskett and Marsden, the Bednarz categories are remarkably limited. Nevertheless, despite their limitations, they were used in two follow-up studies.

The first of these was conducted by Rutherford (2002) and he examined four major geographical education journals, Journal of Geography, Journal of Geography and Higher Education, International Research in Geographical and Environmental Education and Research in Geographic Education. Selecting articles at random, he classified them under three headings: research studies; theoretical synthesis; and non-research. An important finding was that more than half of the articles he had chosen used empirically-based methods to develop theory.

Much more recently, Shin-Cooper has sought to up-date the Bednarz review for the decade 2000 to 2010 (Shin-Cooper, 2012). She set her review in the context of the impact on US schools of the federal No Child Left Behind (introduced in 2001) and Race to the Top (introduced in 2009) initiatives. Reflecting the increasing attention paid to new technologies in geography curricula, she added technology in geography to Bednarz's three categories. Echoing the Bednarz study, she reported that almost half (47.9\%) of the 282 articles reviewed were grouped into the teaching methods and strategies category and, reflecting a culture of educational reform, there was evidence of a growing research interest in institutional studies.

Institutional studies are tied up with what many geographical educators perceive as the always present threats from the 'adjectivals'. This commonly used umbrella term covers a range of courses that, in many countries, have overwhelmed school geography. These include social studies, citizenship education, civics, human rights education, peace education, world studies, European studies, environmental education and education for sustainable development. Challenges to geography as a school subject emanating from these courses and approaches have been present for many decades. Through the curriculum reform movements in places as diverse as Australia (e.g. Powell, 1984 and Maude, 2009), South Africa (e.g. Le Grange. and Beets, 2005) and Hong Kong (Chan, Kwan and Lidstone, 2012) it is possible to trace how governments have sought to locate school geography in new frameworks. Needless to say, reform proposals have spawned reactions from geographical educators who feel that the traditional role of geography in the curriculum has been devalued and 
ought to be defended.

Planners of the school geography curriculum have been able to accommodate some of the adjectivals in geography. This is clearly evident in England where the definition of school geography has been extended to encompass both citizenship education and education for sustainable development. The extent to which this curricular arrangement is able to meet effectively and efficiently the generally accepted definitions of education for sustainable development requires careful research. Can school geography teachers provide courses that cover "environmental, economic and social themes such as poverty alleviation, peace, democracy, justice, human rights, gender equity, economic well-being, social equity, cultural diversity, rural and urban development, environmental protection, and natural resource development"? (Hopkins, 2012, p. 28). Further, education for sustainable development requires a new pedagogy which "shifts the focus away from 'what to teach students' and towards a process of building a learning environment where students of all ages, adults and the community interact and learn together" (Henderson and Tilbury, 2004). This pedagogy is founded on principles of active and participatory learning which "have been broadly agreed as core processes underpinning ESD by a number of researchers and commentators worldwide and across educational settings" (Tilbury, 2011, p. 29). In active and participatory learning learners are encouraged to: "ask critical reflective questions; clarify values; envision more positive futures; think systemically; respond through applied learning; explore the dialectic between tradition and innovation" (Tilbury, 2011, p. 29). Geographical educators will find some encouragement in this list since it parallels much of what is considered to be good practice in their teaching (Lee and Williams, 2006). However, when it is extended to include partnerships in learning between schools and communities and the direct engagement of students in community actions it challenges teachers find moved well beyond the conventional approaches to teaching and learning.

It is not only the adjectivals that challenge geographical educators. Other important challenges come from the rapidly changing communications technologies. There is no doubting the potency of these technologies in informing and educating children, young people and adults in informal and formal ways. They are proving to be a fruitful field of research in geographical education.

Given the stimuli to teachers to innovate from the adjectivals and changing technologies one might expect school geography to provide "students with dynamic, inspirational, relevant and powerful ways of visualizing the world" (Butt, 2011, p. 1). Given the quality of the sophisticated and elaborate geographical education support infrastructure in England, it would be reasonable to expect geography teaching in schools to demonstrate these ways of visualizing the world. In England, there is a well-established specialist geography pre-service and teacher education provision, a network of geographical education researchers, a rich array of producers of geographical education materials, a tradition of fieldwork, an active and influential professional association of geography teachers, and well-established systems of student examinations and specialist school geography inspections. However, in a series of reports (Ofsted, 2004, 2008, 2011) by the schools' inspectorate geography has been given the unfortunate tag of "the worst taught subject in primary schools" (Bell, 2005, p. 13). In 2005, in lower secondary schools it was reported "For many, geography lacks relevance and appeal with the focus on subject content and factual recall rather than stimulating an interest in the world round them and the real issues that will impact on their lives" (Bell, 2005, p. 13). This led to much soul-searching and comparisons being made with the experience of other countries, as evidenced in the Forum edited by Marsden (2005) in International Research in Geographical and Environmental Education. More recently (Ofsted 2011) geography in England is portrayed as being patchy in provision in primary 
schools, with a substantial number of schools making no provision. Many teachers were inadequately prepared and many pupils had weak geographical knowledge. Not surprisingly, perhaps, there was a marked decline in the number of students in the secondary schools electing to study geography for the school leaving examinations. Of course, there are many reasons to explain variations in standards of teaching and student achievement between schools, teachers and students and these are an essential part of any geographical education research agenda. Shin-Cooper (2012), writing in an American context, supported the suggestions for a research agenda in geographical education made by Downs (1994) which included this important statement: "Ultimately, the most important research need in the subfield of geographic education are projects that have the power to transform legislation to include more geographic curricula, encourage decision makers in school districts to mandate that all students study geography, and influence teachers to provide their students with eyeopening experience in carefully tailored lessons".

\section{RESEARCH PROCESSES AND RESEARCH METHODOLOGY}

Whereas the substantive aspects of research in geographical education are currently rooted in the cultures of academic geography, pedagogy and educational studies the research processes and methodology are derived principally from disciplines within the broad fields of the social sciences and the humanities. There is a direct line from research projects in geographical education to projects in education and then to projects in the social sciences and the humanities. Consequently, researchers in geographical education are confronted by a vast array of methods and techniques all of which are very difficult to master. Choosing the appropriate research methods to address an identified research question is never easy.

It is not my intention to review the range of research methods commonly employed in research in geographical education. Such a review was undertaken by researchers drawn from round the world in 1996 (Williams, 1996), supplemented by a collection of papers focused on qualitative research (Gerber and Williams, 1996). While these reflected the methods commonly used by geographical educators at the time they have been surpassed by reviews that have given even more attention to such issues as ethics and such methods as those drawn from phenomenology, ethnography and anthropology (See, for example, the collection of papers brought together by Butt and published in International Research in Geographical Education in 2010 and the papers in Butt, 2011). All that needs to be emphasized here is that researchers must be very familiar with the theories and philosophies underpinning the methods that they are considering as they seek to address a research problem, issue or hypothesis. Without this familiarity, difficulties will arise in terms of the crucial criteria for judging the quality of the research, i.e. honesty, reliability, validity and transferability. These must be acknowledged at each stage of the research process from planning through to initiation, implementation and dissemination. It is worth noting that researchers in geographical education have access to an array of peer-reviewed, prestigious international journals not only from the education sub-fields but also to the social sciences and humanities from whence their research methods have been derived.

\section{SECTORS}

Research studies in geographical education are usually focused two broad sectors: school education and higher education. In recent years there has been a shift in attention from high schools 
(secondary education) to elementary (primary or junior schools). In the 1970s secondary education was the most popular sector. This largely reflected the clear identity of geography in school curricula in most countries. In elementary education geography was often to be found within a number of curriculum frameworks in which the subject had a place though it varied according to the topic or theme being studied. In many countries, the elementary curriculum had clearly identified subject areas for language and mathematics (literacy and numeracy) alongside other approaches that may have focused on nature studies, environmental studies, local studies and so on. These approaches were often described loosely as topic studies or thematic studies. The amount of attention paid to geography varied from topic to topic. The identification of geography as a specific mandated subject in elementary schools in the National Curriculum introduced by law in England in 1988 sparked an increase in the number of teacher educators with special interests in geographical education, generating a network of these specialists, a journal focused on good practice and an increasing number of research publications devoted to this sector. This has been accompanied by research and publications in this sector in other countries. Cross-sector (elementary-secondary) collaboration has been a feature of this increased attention to the education of younger students.

Another important feature has been the parallel development of the field described as children's geographies. Clearly, the study of children's geographies can be conducted without reference to school education. For the purposes of this article it is sufficient to state that the evolution of the sub-field of children's geographies within academic geography represents a trend towards fragmentation that is becoming evident in research in geographical education. Children clearly constitute one constituency and other examples can be drawn from the attention paid to feminist geography and students in higher education.

The field of feminist geography is succinctly defined in the aims of the journal Gender, Place and Culture: A Journal of Feminist Geography (initiated in 1994) devoted to this sub-field:

The aim of Gender, Place and Culture is to provide a forum for debate in human geography and related disciplines on theoretically-informed research concerned with gender issues. It also seeks to highlight the significance of such research for feminism and women's studies. The editors seek articles based on primary research that address: the particularities and intersections of gender, race, ethnicity, age, (dis)ability, sexuality, class, culture and place; feminist, anti-racist, critical and radical geographies of space, place, nature and the environment; feminist geographies of difference, resistance, marginality and/or spatial negotiation; and, critical methodology. (http://www.tandfonline. com/action/aboutThisJournal?show=aimsScope \&journalCode=cgpc20 : Accessed: October 2012)

How far these aims are being met can be garnered from a review conducted by Johnson (2008)

Gender figures in research in geographical education though, as yet, it has not taken on the characteristics evident in this quotation and, as a review of the journal conducted by Johnson (2008) shows, education has not figured prominently in that journal. It is a reminder of the range of constituencies that can be used as the basis for studies by geographical educators including migrants, economically and socially disadvantaged groups; advantaged groups; racial groups; religious groups, and so on. While emphasizing constituencies in this way the door is opened for scholars narrowly interested in one or more of them to introduce their own communities of interest leading to fragmentation of the sub-field of research in geographical education.

An obvious example of this fragmentation is to be found in the higher education sector. Research 
in this sector has evolved particularly since the publication of the first issue of the Journal of Geography in Higher Education in 1977 with the following aim:

The Journal of Geography in Higher Education (JGHE) was founded upon the conviction that the development of learning and teaching was vitally important to higher education. It is committed to promote, enhance and share geography learning and teaching in all institutions of higher education throughout the world, and provides a forum for geographers and others, regardless of their specialisms, to discuss common educational interests, to present the results of educational research, and to advocate new ideas. (http://www.tandfonline.com/action/aboutThisJournal?show=aimsScope\&jo urnalCode $=$ cjgh20 Accessed: October 2012)

This journal has to be set in the context of an evolving infra-structure that includes collaborative research studies, national and international conferences, national and international networks and publications additional to the journal.

Reference has already been made to the dominant role of teacher educators in research in geographical education. Not surprisingly, this has resulted in the build-up of a substantial number of studies focused on the processes of teacher education. As yet, teacher education specialists as a group or as a community of scholars have not broken away from the organisations and publications concerned with school education. It is possible to envisage an International Journal of Geography in Teacher Education that acknowledges the amount of research attention paid to teacher education. Of course, it could be argued that there is no shortage of journals focused on teacher education in which specialists in geographical education may publish.

What is most noticeable about geographical education is that it attracts a great deal of research attention in schools, teacher education institutions and higher education institutions but as regards the post-education sectors of adult learning and the learning of elders such research ceases. Indeed, as yet there are no parallels to studies of children's geographies. There are no journals titled Youth Geographies or Adults' Geographies or Elders' Geographies though there are occasional studies scattered through academic geography journals.

Geography would appear to be a subject worthy of formal study in educational institutions attended by children and students but outside these institutions it is much more difficult to detect. What this alerts us to is the need to consider geographical education in the context of lifelong learning. Lifelong learning is a loose term sometimes translated simply into vocational education and driven by the need for professionals and workers to continue to develop and enhance their skills base throughout their working lives. At other times lifelong learning is conceptualized as liberal education, where learning in undertaken for its own sake. What is clear is that lifelong learning, outside of the continuing professional development of teachers, has failed to attract the attention of geographical educators.

The arrangements made for the provision of formal learning opportunities for adults varies from country to country and in some countries the provision of adult education takes precedence over school provision. What is more universal is that adults learn about geographical issues and topics informally. It is usually self-directed and sporadic rather than organized and sustained. The sources are many but easy and cheap access to television and the internet is, for many though certainly not all, a key factor. Geography may not figure in the titles of television programmes or in the titles of webpages but the content may be very specifically geographical. There are also in some societies 
educational programmes with a strong geographical element education directed at adults through a variety of voluntary, non-governmental and public agencies. This is particularly evident in lessdeveloped countries where programmes are frequently vocational and community-based. Not only is the effectiveness of these programmes of interest to geographical educators in terms of the geographical, knowledge, skills and values that may be acquired by individuals but also in terms of the methods employed to facilitate individual and community group learning. For school-based geographical educators there may be much to learn from what has been termed andragogy (Knowles, 1978; Gerber and Williams, 2002). Certainly, there is a great deal in this to be researched.

One aspect of geographical education for adults deserves special mention and that is the education of parents. There are good functional reasons for researching this. Parents can contribute to their children's motivation, interest and enthusiasm for geography. They have the capacity not simply to guide students when they make choices about subjects to study in school and courses to follow post-school but also to enhance or hinder the geographical studies of their offsprings. There have been interesting projects undertaken in schools focused on parents as teachers though, as far as I aware, these have not been conducted in the context of school geography. Not only is the contribution of parents to their offsprings' education of interest, just as interesting is the contribution made by students to their parents' geographical education. There is some evidence for this with regard to education for sustainable development, e.g. the My Neighbourhood, My Land, My Treasure project in Brazil, (Soares, Petarnella and Garcia, 2011), the Enviroschools Program in New Zealand (Williams, 2012) and the Education for Sustainable Development Project in Hong Kong (Lee, Lam and Williams, 2009). Intergenerational learning is a research topic in geographical education waiting to be researched.

\section{IMPACT}

More than a decade has elapsed since I wrote (Williams, 2003).

Establishing causal relationships between findings from educational research and subsequent behavior, whether it be policy making, pedagogical changes or further research is extremely difficult. It would be very satisfying to be able to identify seminal research studies that led directly to clearly demonstrated changes, especially to substantial changes in policies or practices.

Researchers, no doubt begin their projects with the optimistic sense that their findings will make a difference. The question arises as to where that difference is to be found? Recipients of such research are in various categories including, in no rank order:

- Other researchers in geographical education and associated adjectivals;

- Other researchers in education;

- Curriculum policy makers and planners at national, regional, local and institutional levels;

- Providers of pre-service and in-service education for teachers.

- The mass media; 
- Producers of educational materials (publishers, broadcasters, equipment manufacturers);

- Non-governmental and voluntary organisations.

For some research studies the targets within these groups may be clear at the outset of the studies. This will be particularly so for funded projects where the funding agency may specify the target audiences. For others, the significance and reliability of the findings are likely to determine the audience.

Researchers are prone to moan about the lack of attention paid by potential readers to their work. There is often an inbuilt assumption that publications from geographical education research are read only by other professionals in the geographical research community. The impact, in these circumstances, is to be found in the citations of publications and in the use made by fellow-researchers of the publications in their studies.

With regard to government agencies, if there was a serious interest in research findings in geographical education then they would be very active in commissioning and funding relevant studies. Such funding across the globe is rare. Geographical education, apparently, has a low priority compared with what are commonly referred to as the core subjects in schools (language and literacy, mathematics and numeracy, science and foreign languages) where any funding is more readily accessible. There is considerable scope for cross-cultural studies of curriculum policy with particular reference to the linkages between research findings and curriculum decision-making. Much the same can be said of the linkages between reforms and innovation in in geographical education and pre-service and in-service teacher education.

\section{CONCLUSION}

Over the last two decades the sub-field of research in geographical education has been transformed and this transformation is evidenced in a variety of forms. The dominance of Anglo-American-Australian researchers has weakened as more researchers from many more countries undertake research projects, sometimes conducted as cross-national collaborative projects. The variety of topics studied reveals the idiosyncrasies of individual researchers, on the one hand, and the concerns of national and other policy makers, professionals and various agencies. The increasing politically driven concerns with research standards in many countries has brought an intense interest among researchers in the kind of studies they undertake, the quality of the publications in which they seek to disseminate their findings and in the standing of conferences which they attend. There is an increasing awareness of a hierarchy in research activity in general and a particular hierarchy in research in geographical education.

A particular problem for researchers in geographical education has been determining the journals to which they should submit their research papers: education journals or geographical education journals; national journals or international journals; journals focused on particular research methods or journals focused on the persons studied. Where groups find difficulties in having their work accepted in existing journals there is a temptation to establish new journals and then these locate them in the contemporary quality hierarchy.

The assumption of the previous paragraph is that researchers in geographical education see other 
researchers as the prime audience for their work. Researchers from small countries who write in minority languages, and see the prime audiences for their work as being interested readers in their own language, struggle to see their work in print. Potential readership numbers do not justify conventional publishing of journals and books. It is in these circumstances that the potential of the internet becomes particularly significant. It is also in these circumstances that collaborative projects are particularly important. There is mutual benefits for collaborators and there are also benefits for individual researchers who are enabled to become part of a community of scholars.

Finally, there are many places, local, national and international, where researchers in geographical education can share their experiences. One such is the programme of meetings arranged by the Commission on Geographical Education of the International Geographical Union. Information about these meetings can be gained from the electronic newsletter accessible on its website: http:// www.igu-cge.org/. In 1992 the Commission launched an International Charter on Geographical Education and this has been translated into some 22 languages. Given the importance of research in the activities of the Commission the time is ripe for the preparation of a similar charter specifically concerned with research in geographical education. Such a charter would include many of the elements indicated in the framework illustrated in Figure 1.

\section{REFERENCES}

Bednarz, S. (2000). Education research in the Journal of Geography 1988-1997. International Research in Geographical and Environmental Education, 9 (2), 128-141.

Bell, D. (2005). The value and importance of geography. Teaching Geography. 30 (1), 12-13.

Butt, G. (ed.) (2011). Geography, Education and the Future. London: Continuum.

Butt, G. (2010). Which methods are best suited to the production of high-quality research in geography education? International Research in Geographical and Environmental Education, 19 (2), 103-107.

Chan, E., Kwan, T. and Lidstone, J. (2012). Changing Conceptions of Teaching and Learning in Hong Kong: from Geography to Liberal Studies. Hong Kong: INSTEP, Faculty of Education, The University of Hong Kong.

Convey, A. and Nolzen, H. (eds.) (1997). Geographie und Erziehung. Munchen Studien zur Didaktik der Geographie. Munich: University of Munich.

Downs, R. M. (1994). The need for research in geography education: it would be nice to have some data. Journal of Geography, 93 (1), 57-60.

Downs, R. M., Liben L. S and Daggs, D. G. (1988). On education and geographers: the role of cognitive developmental theory in geographic education. Annals of the Association of American Geographers, 78 (4), 680-700.

Foskett, N. and Marsden, B. (eds.) (1998). A Bibliography of Geographical Education 1970-1997. Sheffield: Geographical Association. 
Foskett, N. and Marsden, B. (eds.) (1998). A Bibliography of Geographical Education 1970-1997. Sheffield: Geographical Association.

Gerber, R. (ed.) (2003). International Handbook on Geographical Education. Dordrecht: Springer.

Gerber, R. and Williams, M. (eds.) (1996). Qualitative Research in Geographical Education. Armidale: University of New England Press

Gerber, R. and Williams, M. (2000). Research and geography teaching: overview and international perspectives. In A. Kent (ed.) Reflective Practice in Geography Teaching, London: Paul Chapman/Sage.

Gerber, R. and Williams, M. (eds) (2002). Geography, Culture and Education. Dordrecht: Springer.

Gerber, R. and Williams, M. (2002). Geographical education and the challenge of lifelong learning. In R. Gerber, and M. Williams (eds.) Geography, Culture and Education. Dordrecht: Springer.

Haubrich, H, (ed.) (1987). International Trends in Geographical Education. Freiburg: Commission for Geographical Education of the International Geographical Union.

Henderson, K. and Tilbury, D. (2004). Whole-School Approaches to Sustainability: An International Review of Sustainable School Programmes. Report Prepared by the Australian Research Institute in Education for Sustainability (ARIES). Canberra: Department of the Environment and Heritage.

Hopkins, C. (2013). Education for sustainable development in formal education in Canada. In R. McKeown and V. Nolet (eds.) Schooling for Sustainable Development in Canada and the United States. Dordrecht: Springer.

Humphrys, G. and Williams, M. (eds.) (2005). Presenting and Representing Environments. Dordrecht: Springer.

Johnson, L. C. (2008). Re-placing gender? Reflections on 15 years of Gender, Place and Culture Reubicando el género? Reflexiones sobre 15 años de Gender, Place and Culture. Gender, Place and Culture: A Journal of Feminist Geography 15 (6), 561-574.

Kidman, G. and Papadimitrou, F. (2012). Content analysis of international research in geographical and environmental education: 18 years of academic publishing. International Research in Geographical and Environmental Education, 21 (1), 3-10.

Knowles, M. S. (1978 2nd. edn.) The Adult Learner: A Neglected Species. Houston: Gulf Publishing Company.

Lee, J. C-K and Williams, M. (eds.) (2006). Environmental and Geographical Education for Sustainability. NewYork: Nova Science Publishers, Inc.

Lee, J. C-K and Williams, M. (eds.) (2009). Schooling for Sustainable Development in Chinese 
Communities: Experience with Younger Children. Dordrecht: Springer.

Lee, J. C-K, Lam, W-P. and Williams, M.(2009). The Education for Sustainable Development Project in Hong Kong. In J. C-K. Lee and M. Williams, (eds.) Schooling for Sustainable Development in Chinese Communities: Experience with Younger Children. Dordrecht: Springer.

Le Grange, L. and Beets, P. (2005). Geography education in South Africa after a decade of democracy. Geography 90 (3), 267-277.

Lidstone, J. and Williams, M. (eds.) (2006). Geographical Education in a Changing World: Past Experiences, Current Trends and Future Challenges. Dordrecht: Springer.

Lidstone, J. and Williams, M. (2006). Researching change and changing research in geographical education. In J. Lidstone and M. Williams (eds.) Geographical Education in a Changing World: Past Experiences, Current Trends and Future Challenges. Dordrecht: Springer.

Lukehurst, C. T. and Graves, N. (eds.) (1972). Geography in Education: A Bibliography of British Sources 1870-1970. Sheffield: Geographical Association.

Maude, A. (2009). Re-centring geography: a school-based perspective on the nature of the discipline. Geographical Research 47 (4), 368-379.

McKeown, R. and Nolet, V. (eds.) (2013). Schooling for Sustainable Development in Canada and the United States. Dordrecht: Springer.

Ofsted (2004). Ofsted Subject Reports 2002/03: Geography in Primary Schools. London: HMSO.

Ofsted (2008). Geography in Schools: Changing Practice. London: HMSO.

Ofsted (2011). Geography: Learning to make a world of difference. London: HMSO.

Papadimitrou, F. and Kidman, G. (2012). Statistical and scientometric analysis of international research in geographical and environmental education. International Research in Geographical and Environmental Education, 21 (1), 11-20.

Powell, J.M. (1984). Curriculum reform and the 'constituency' challenge: recent trends in school geography. Australian Geographical Studies 22 (2), 275-285.

Roberts, M. (2011). Conclusion. In G. Butt (ed.) Geography, Education and the Future. London: Continuum.

Rutherford, D. (2002). Building empirically-based theory in geography education. International Research in Geographical and Environmental Education, 11 (3), 283-286.

Shin-Cooper, J. (2012). Has geography education research grown in the past decade? A typology review of research in the Journal of Geography, 2000-2010. http://geography.uoregon.edu/ edge/EDGE/Projects/2012/J_Shin_Cooper_2012.pdf. Accessed Oct. 4th 2012. 
Soares, M. L. de A. and Petarnella, L. (eds.) (2011). Schooling for Sustainable Development in South America. Dordrecht: Springer.

Soares, M. L. de A., Petarnella, L. and Garcia, E. de C. (eds.) (2011). Education for sustainable development: experience with students of early childhood education in the State School Paulo Tapajós, São Paulo/Brazil. In M. L. de A. Soares, and L Petarnella (eds.) Schooling for Sustainable Development in South America. Dordrecht: Springer.

Tilbury, D. (2011). Education for Sustainable Development: An Expert Review of Processes and Learning. Paris: UNESCO.

Williams, M. (ed.) (1996). Understanding Geographical and Environmental Education: the Role of Research, London: Cassell.

Williams, M. (1997). Research in geographical education: retrospect and prospect. Geographie und ihre Didaktik, 3 (26), 124-135.

Williams, M. (1999). Research in geographical education. International Research in Geographical and Environmental Education, 8 (3), 301-304.

Williams, M. (2003). Research in geographical education: the search for impact. In R. Gerber (ed.) International Handbook on Geographical Education. Dordrecht: Springer.

Williams, M. (2005). Environmental education and lifelong learning: awareness to action. In G. Humphrys and M. Williams (eds.) Presenting and Representing Environments. Dordrecht: Springer.

Williams, M. and Humphrys, G. (eds.) (2003). Citizenship Education and Lifelong Learning: Power and Place. New York: Nova Science Publishers, Inc.

Williams, P. (2012). Education for sustainability in New Zealand; success through Enviroschools. In M. Robertson (ed.) Schooling for Sustainable Development: A Focus on Australia, New Zealand and the Oceanic Region. Dordrecht: Springer. 